Florida International University FIU Digital Commons

FIU Electronic Theses and Dissertations

University Graduate School

6-4-2004

\title{
Program notes and translations for a graduate voice recital
}

Sara Arias Ruiz

Florida International University

DOI: $10.25148 /$ etd.FI14032343

Follow this and additional works at: https://digitalcommons.fiu.edu/etd

Part of the Music Commons

\section{Recommended Citation}

Arias Ruiz, Sara, "Program notes and translations for a graduate voice recital" (2004). FIU Electronic Theses and Dissertations. 1060. https://digitalcommons.fiu.edu/etd/1060

This work is brought to you for free and open access by the University Graduate School at FIU Digital Commons. It has been accepted for inclusion in FIU Electronic Theses and Dissertations by an authorized administrator of FIU Digital Commons. For more information, please contact dcc@fiu.edu. 
FLORIDA INTERNATIONAL UNIVERSITY

Miami, Florida

PROGRAM NOTES AND TRANSLATIONS

FOR

A GRADUATE VOICE RECITAL

A thesis submitted in partial fulfillment of the

requirements for the degree of

MASTER OF MUSIC

by

Sara Arias Ruiz

2004 


\section{To: Dean R. Bruce Dunlap}

College of Arts and Sciences

This thesis, written by Sara Arias Ruiz, and entitled Program Notes and Translations for a Graduate Voice Recital, having been approved in respect to style and intellectual content, is referred to you for judgment.

We have read this thesis and recommend that it be approved.

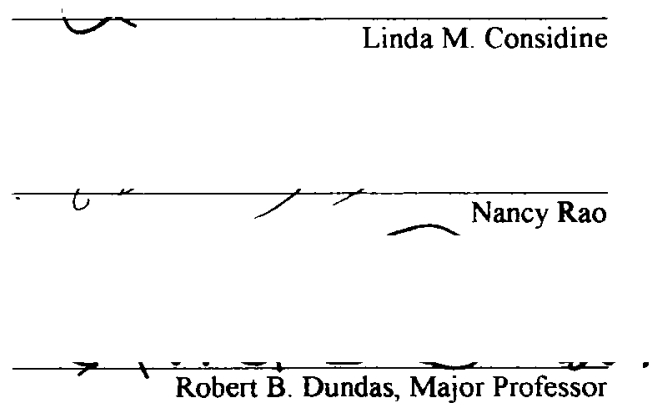

Date of Defense: June 4, 2004

The thesis of Sara Arias Ruiz is approved

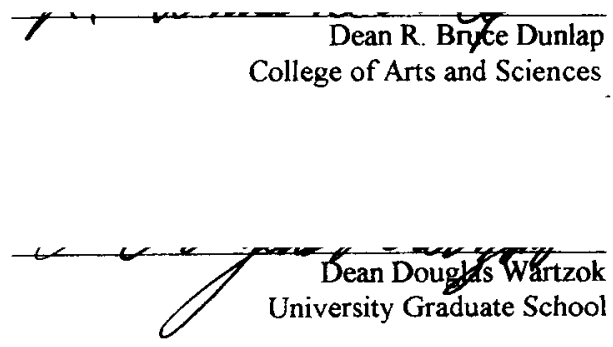

Florida International University, 2004 


\section{ABSTRACT OF THE THESIS}

PROGRAM NOTES AND TRANSLATIONS FOR A GRADUATE VOICE RECITAL

by

Sara Arias Ruiz

Florida International University, 2004

Miami, Florida

Professor Robert B. Dundas, Major Professor

"Già il sole dal Gange"

Alessandro Scarlatti

"O cessate di piagarmi"

$(1660-1725)$

"Spesso vibra per suo gioco"

"Must the winter come so soon"?

Samuel Barber

from Vanessa

(1910-1981)

Two Songs from Mirabai Songs

John Harbison

"It's True I Went to the Market"

"Don't Go, Don' Go"

El amor brujo

"Canción del amor dolido"

Manuel de Falla

"Canción del fuego fatuo"

(1876-1946)

"Danza del juego del amor"

"Las campanas del amanecer"

Franz Schubert

(1797-1828)

"Ständchen" from Leise

"Gretchen am Spinnrade" D257

\section{INTERMISSION}

"Una voce poco fa"

Gioachino Rossini

from $I$ barbiere di Siviglia

(1792-1868)

La Regata Veneziana - Three songs in Venetian dialect

"Anzoleta avanti la regata"

"Anzoleta co passa la regata"

"Anzoleta dopo la regata" 
I. NTRODUCTION I

II. PROGRAM NOTES 2

Alessandro Scarlatti

"Giá il sole dal Gange"

"O cessate di piagarmi"

"Spesso vivra per suo gioco"

Gioachino Rossini

La Regata Veneziana - three songs in Venetian dialect

"Anzoleta avanti la regatta"

"Anzoleta co passa la regatta"

"Anzoleta dopo la regatta"

"Una voce poco fa" from Il barbiere di Siviglia

Franz Schubert

8

"Ständchen"

"Du bist die Ruh" D776

"Gretchen am Spinnrade" D257

Manuel de Falla

El amor brujo:

"Canción del amor dolido"

"Canción del fuego fatuo"

"Danza del juego del amor"

"Las campanas del amanecer"

John Harbison

Two songs from Mirabai Songs

"It's true I went to the Market"

"Don't Go, Don't Go"

Samuel Barber

"Must the winter come so soon"? from Vanessa

LIST OF REFERENCES 


\section{INTRODUCTION}

The repertoire chosen for this recital consist of literature for mezzo-soprano voice in Italian, German, Spanish and English, and it represents the Baroque, Classical, Romantic and Contemporary periods. The following program notes and translations are intended to provide an audience with background for enhanced appreciation of the text and music for each section. A list of references used for this document is provided at the conclusion.

The performance of this recital was given in the Recital Hall of Wertheim Performing Arts Center on June 4, 2004. All members of the recital committee were in attendance. Georgi Danchev was the collaborative pianist. 


\section{SECTION II}

Giá il sole dal Gange

O cessate di piagarmi

Spesso vivra per suo gioco

Alessandro Scarlatti (1660-1725) is considered the founder of the Neapolitan school of opera. His works form the most important link between the tentative "new music" of the $17^{\text {th }}$ century and the classical school of the $18^{\text {th }}$ century. He composed mainly for the stage. The comic scenes in his nearly eighty-five operas feature realistic dialogue and local dialect. Scarlatti's operas consist primarily of recitatives and arias, typical of the opera seria style. Recitatives are used to carry on conversations and move the story along. Arias are vehicles to express deeper, more personal emotions. The typical Baroque aria is in da capo form and it features repetitive text, motivic development, challenging vocalization and tonal unity. ${ }^{1}$ For this reason, arias became the most important element in Neapolitan operas. The popularity of the new Neapolitan style of opera spread rapidly through Europe.

The "canzonetta" Giá il sole dal Gange (The Sun on the Ganges) is from the opera L'Honestà negli amori, (Honesty in Love Affairs) written in 1680 . The singer is a page boy, Saldino. Giá il sole dal Gange is one of the composer`s best-known and most often performed arias. The poem is by Felice Parnasso and the words refer to the rising sung, sparkling on the river Ganges. ${ }^{2}$

\footnotetext{
${ }^{1}$ Carol Kimball. Song: A guide to Style \& Literature. Redmond, Washington: Pst... Inc., 2000,353.

${ }^{2}$ John Glenn Paton. 26 Italian Songs and Arias. Van Nuys, California: Alfred Publishing Co., Inc.34.
} 
O cessate di piagarmi is from Scarlatti's opera Pompeo written in 1683, the plot is based on ancient Roman history. The singer is Sesto, son of the Roman general, Pompey the Great. Sesto sings of his love for Issicratea, Queen of Pontus, living under house arrest in Rome. "O cease to Wound $\mathrm{Me}^{m}$ is a two strophe lament set against a persistent bass line. The tempo marking is andante con moto: the second strophe is to be sung at a slower tempo than the first. The word lasciatemi (let me) and the word sorde (deaf) are highlighted through the melody. The unyielding $6 / 8$ rhythm of the accompaniment helps to sustain the mood of despair. ${ }^{3}$

Spesso vivra per suo gioco is a canzonetta about Cupid (God of love) and how he makes people fall in love regardless of the victims desire to experience this pleasure. The melody and the accompaniment are made up of triplet figures and dotted quarter notes. The tempo (allegro) together with the rhythm help to portray Cupid's excitement when throwing love's darts.

\footnotetext{
${ }^{3}$ Carol Kimball. Song: A Guide to Style \& Literature. Redmond, Washington: Pst... Inc., 2000, 353.
} 
La Regata Veneziana - three songs in Venetian dialect:

Anzoleta avanti la regata

Anzoleta co passa la regata

Anzoleta dopo la regata

Una voce poco fa from Il Barbiere di Siviglia

Rossini (1792-1868) was born in Pesaro, Italy, to musician parents. The composer began his operatic writing at age 18 . Rossini was very prolific, composing at one point up to 7 operas in the span of 16 months. He wrote a total of 39 operas. His operas, both buffa and seria, showed his mastery of the bel canto school of composition. With florid lines, vocal embellishments, incredible speed and spontaneity, Rossini created some of the most unforgettable music in the operatic repertoire. By 1825 Rossini had conquered all the major opera theaters of Europe. However, just a few years later, and due to poor health, he decided to retire from opera. In 1857 he moved to Paris with his wife Olympe Pélissier.

In 1858 Rossini purchased land for a villa in the Paris suburbs of Passy. He was soon asked by friends and publishers to provide new songs for the musical soirées which took place at his villa. In December of that year Rossini held the first of their famous soirées, the Samedi soirs, for which invitations were much in demand. Every Saturday Rossini's salon became a meeting place for composers, artists and friends. The evening would have a pre-arranged musical program, mostly of Rossini's own compositions and with the composer at the piano. Many young singers made their debuts at these Saturday's gatherings. The evening would also include a magnificent meal. Rossini was a very famous gourmet, and he took great pride in his table and underground store. 
He loved fine wines, and exchanged recipes with the famous chefs of the Paris. His humor was legendary, and his witty remarks were circulated around Paris for all to enjoy. Honored and courted, Rossini grew old serenely, composing whenever inspiration came to him. In these years he wrote Le Chant des Titans (1859), the Petite Messe solennelle (1863), the Hymne à Napoléon III (1867), and various pieces of chamber music including the Péchés de vieillesse (Sins of old age.) The famous soirées would continue for the next ten years. The last occurred September 26, 1868. The composer's chronic ill health finally overcame him and he died two months later.

La Regata Veneziana belongs to the Album Italiano (Italian Album,) part of Péchés de vieillesse (Sins of Old Age.) The three songs were written in 1858 and describe the famous Venetian regatta from the viewpoint of a young woman, Anzoleta. She watches her boyfriend Momolo prepare for the regatta, win the race, and present her with the red flag of victory. These songs, although written during a more mature and elaborate phase of Rossini's development, maintain a folk-like simplicity of spirit and line. The piano accompaniment consists for the most part of broken-chord variations used to portray the water's movements, as well as the excitement of the crowd. Anzoleta avanti la regata (Anzoleta before the race.) The first song provides the listener with valuable information about the regatta's heroine, Anzoleta. She is a young, smart, and ambitious girl. She truly loves Momolo and she is convinced that he can win the race. From the text we learn that this young man (although very talented in the art of rowing) is a bit hesitant to participate in the boat race. The piano introduction illustrates Anzoleta's excitement when she sees the waving pennants. The harbor is full with people and the music portrays everyone's hopes and expectations. 
Anzoleta co passa la regata (Anzoleta during the race.) The introduction to this song reminds us of Rossini's ingenius gift for music. The piano not only clearly portrays the fast water movement and the racing boat, but also Anzoleta's racing heart. The nervousness, madness and anxiety felt by the heroine is expressed by the insistent rhythm in the accompaniment. Despite her fear, Anzoleta loudly urges Momolo to keep on rowing.

Anzoleta dopo la regata (Anzoleta after the race.) The last of the three songs begins with a glorious Napoleonic-style triumphal march. Momolo is the winner. All Venice is talking about him. Anzoleta is filled with pride and joy. In return for his winning the race, Anzoleta showers Momolo with kisses.

Il Barbiere di Siviglia was written in 1816. The libretto is by Cesare Sterbini after Le Barbier de Séville (1775), a comedy by Pierre Augustin Caron de Beaumarchais. The opera was first performed at the Teatro Argentina in Rome on February 20, 1816. The aria Una voce poco fa is from Act 1 , scene 2 . It introduces the character of Rosina, the young ward of old Dr. Bartolo, who wants to marry her. Rosina is in her room thinking of her love, Lindoro (the Count Almaviva in disguise.) He has been serenading her and they have exchanged notes. During this aria she swears to trick Dr. Bartolo and succeed in following her romantic yearnings.

Una voce poco fa opens with a 13 measure orchestral introduction, leading to a recitative-like section followed by a faster, more song-like section. The melody contains clearly defined repeated motives and phrases. The instrumentation is sparse, typical of Rossini's style, and does not interfere with the voice part. The colorful sound within the 
vocal part is achieved through the use of accidentals, dotted rhythms, repeated motives and phrases. 


\section{Ständchen}

\section{Du bist die Ruh}

\section{Gretchen am Spinnrade}

The Austrian composer Franz Schubert (1797-1828) wrote symphonies, operas, masses, piano music, and over 600 Lieder (songs) during his brief 31 years of life. He produced the first significant song cycles, the most famous of which are Die schöne Müllerin and Winterreise. Each is remarkable for its quality, character and popularity. Schubert's songs have classical form and expressive melodies and harmonies. They were composed in a variety of formal structures: strophic, strophic with variations, declamatory and through-composed. The accompaniment always plays a very important role in Schubert's music, either as a commentator on the text or setting the mood to the entire piece. Schubert set the texts of about ninety poets, among them Goethe, Müller, Schiller, Heine and Rückert, choosing poetic themes of life, death, happiness or misery. He was a great innovator, exerting a huge influence over his contemporaries as well as later generations of composers. Brahms wrote: "There is not a song of Schubert's from which one cannot learn something." The three songs chosen for this recital demonstrate Schubert's genius for dramatic characterization, youthful enthusiasm and his expression of ecstatic love.

Ständchen is song number 4 of the 14 songs that make up Schwanengesang, D. 957. This collection of lieder was composed in 1828 and published as a cycle shortly after Schubert's death. It is one of the composer's most beloved works and Ständchen is one of its more popular songs. The text by Ludwig Rellstab (1799-1860) is about love and youthful enthusiasm. Being a serenade, the piano holds a conversation with the 
melody of the singer. The piano responds to what the voice is saying with a very light guitar-like plucking sound. The rhythm remains constant throughout the song suggesting the sincere determination of the singer. The poet chooses an $\mathbf{a - b - a - b}$ pattern for the text, typical of the popular "folk" poetry of the time. This adds a simple rustic quality to the song.

Du bist die Ruh D.776 is a slow, fervent ode to an ideal love. The poem is by Friedrich Rückert (1788-1866) and expresses a deep sense of agreement and contentment among the lovers. Schubert uses the piano introduction to set the mood and tone of the song. The slow $3 / 4$ meter has the soothing quality of a lullaby. The piano maintains this background throughout the song, changing ingeniously from minor to major keys in support of the text. Schubert was also a master of "word painting" technique. An excellent example can be found in the forth stanza when he uses the words "the heart is full." Here the notes and the voice swell on the word "full." The song's form is ABABC.

Gretchen am Spinnrade was composed in 1814 and is considered Schubert's first masterpiece. The text was adapted from Goethe's epic play Faust. The scene depicts Gretchen's desperate feelings towards her beloved Faust. She is alone, sitting at the spinning wheel remembering how he made love to her. The work's texture is homophonic but the voice and the accompaniment work independently. The piano portrays the spinning wheel and, depending on Gretchen's emotional state, conveys her feelings and emotions through dramatic and agitated effects. The successive $16^{\text {th }}$ note figures in the piano are set against a lyric vocal line that consists mainly of half steps and closely related notes. Similar phrases are repeated, sometimes with variations. 
Gretchen's heightened emotions are shown through expressive harmonic progressions and modulations related closely to the text. 


\section{El amor brujo:}

\section{Canción del amor dolido}

Canción del fuego fatuo

Danza del juego del amor

Las campanas del amanecer

Manuel Maria de Falla y Matheu (1876-1946) received his early musical education in Cadiz and Madrid. He lived in Paris from 1907 to 1914, where he was influenced by such French composers as Debussy, Ravel, Dukas, Faurè. He also become acquainted with the Spanish composers like Albeniz, Turina and the pianist Ricardo Viñes all of whom encouraged De Falla to develop his powerful, individual nationalistic style. Indeed, his music reflects the passionate intense and flamboyant personality and culture of Spain.

Among his most significant works is the one act ballet El amor brujo (Love the Magician) composed from 1914-1915. It refers to a gypsy ghost story. The heroine Candela is possessed by the ghost of her late husband José. The ghost is jealous of the attentions being paid by her to his successor, Carmelo, who has been in love with Candela since childhood. José's ghost attempts to interrupt the new romance. At the same time another gypsy girl, Lucia, eternally lusts after José. She flirts with him (his ghost) with the intention of distracting him so that Candela and Carmelo can be together and, as a consequence, she can have him for herself.

The text of the ballet's four songs is by Gregorio Martinez Sierra (1881-1947) The composer uses the music of the Spanish flamenco and cante-jondo, a generic term encompassing the purest and oldest strata of songs of the flamenco tradition, which 
originated in the provinces of Andalusia in southern Spain. While cante hondo (or, in its aspirated, Andalusian form, jondo) refers, more appropriately "to a particular vocal timbre. The term has been used erroneously to designate a form. Hondo connotes a deep or profound feeling with which the singer expresses his or her innermost thoughts, emphasizing the tragic side of life."4

Canción del amor dolido (Song of the aching love.) The action takes place in Cádiz at night time. The gypsies throw the cards to discover their fates. Candela, sad for love, sings that she doesn't know what she feels, neither does she know what is happening to her without her lover.

Canción del fuego fatuo (Song of the Saint Elmo's fire.) This song takes place after the intermission. The setting is a mysterious witches cave. Candela enters and sings. She says that love is like Saint-Elmo's fire. If you try to run away from it, it will follow you; if you call it, it will run away!

Danza del juego del amor (Dance of love's game.) Candela casts a spell. Her lover arrives and Candela sings and dances. She sings to her former husband José. Candela refers to him as that bad gypsy that she once loved. The love she gave to him, he did not deserve it.

Las campanas del amanecer (The bells at sunrise.) The bells announce the beginning of a new day as well as the lovers Candela and Carmelo's reconciliation.

\footnotetext{
4 J.B. Trend/Israel J. Katz: "Cante Hondo," Grove Music Online ed. L. Macy (Accessed [3 April 04]), $<$ http://www.grovemusic.com>
} 
Two songs from Mirabai Songs

It's true I went to the Market

Dont Go, Dont Go

John Harbison is a composer, conductor, teacher, poet, and a gifted commentator on the art and craft of contemporary composition. He was born in Orange, New Jersey on 20 December 1938 to a family of musicians. He is one of America's most prominent living composers. His music is performed all over the world by most of the leading ensembles and it is distinguished by its exceptional resourcefulness and expressive range. He has written for every conceivable type of ensemble and genre.

Harbison did his undergraduate studies at Harvard University and earned an MFA from Princeton University. He is the winner of multiples prizes and awards (among them a Pulitzer Prize, the Kennedy Center Friedheim First Prize, the Heinz Award for the Arts and Humanities (1998), Distinguished Composer award from the American Composer's Orchestra (2002), the Harvard Arts Medal (2000), the American Music Center's Letter of Distinction (2000), and a MacArthur Fellowship (1989.) He also holds four honorary doctorates.

One of Harbison's prime interests is furthering the work of younger composers. He serves on the board of directors of the Copland Fund (as president) and the Koussevitzky Foundation. His music is published exclusively by Associated Music Publishers. The Mirabai Songs were written by John Harbison in 1982.

Because of her late dates and her higher social status, more is known about Mirabai than about any other Indian women poets. She was born in Rajasthan to a Rajput 
noble family, and was married in about 1516 to the heir-apparent of the ruler of Mewar. ${ }^{5}$ Her husband died before he could attain the throne and he left no heir. Mirabai refused to die on her husband's funeral pyre, as was the custom of the time. Instead, she left her family compound, wrote her poems to Krishna, the Dark One, and sang and danced them in the streets. ${ }^{6}$ The poems of Mirabai, selected and set to music by Harbison, were translated into English by Robert Bly.

It's true I went to the Market is song number one of the six that embody the cycle. The composer dedicated this song to the American mezzo-soprano, Janice Felty. From this song we learn how Mirabai chose to live by and for Krishna. According to Hindu mythology Krishna is the eighth incarnation of lord Vishnu and was born in the Dvarpara Yuga as the "dark one." Krishna is the embodiment of love and divine joy that destroys all pain and sin. He is the protector of sacred utterances and cows. He is also a trickster and lover, and instigator of all forms of knowledge, born to establish the religion of love.

Don 4 Go, Don 4 Go is the last of the six songs. The composer chooses a very slow tempo and the piano accompaniment, made up mainly of quarter and eight notes, moves in a very cantabile, legato motion that supports the very sad melodic line. Harbison makes use of accidentals to support the ascending and descending chromatic lines. The composer dedicated this song to American soprano Susan Quittmeyer.

\footnotetext{
${ }^{5}$ Other women's voices online (accessed [12 January 04]) <http:/home.infionline.net/ ddisse/mirabi.html $>$

${ }^{6}$ John Harbison Mirabai Songs. New York, NY: Associated Music Publishers, Inc., 1988.
} 
Must the winter come so soon?

Samuel Barber (1910-1981) was, along with Aaron Copland and Giancarlo Menotti, the most frequently performed American composer of his generation. From 1941 until the end of his life, he lived to see almost all of his music recorded. Barber composed three operas Antony and Cleopatra, Vanessa, and A Hand of Bridge. All them are masterfully crafted and built on romantic structures and sensibilities. They are at once lyrical, rhythmically complex, and harmonically rich.

Barber wrote his first composition at age 7 and attempted his first opera at age 10. At the age of 14 he entered the Curtis Institute, where he studied voice, piano, and composition. Later, he studied conducting with Fritz Reiner. At Curtis, Barber met Gian Carlo Menotti with whom he would form a lifelong personal and professional relationship. Menotti supplied libretti for all of Barber's operas. The composer's music was championed by a remarkable range of renowned contemporary artists, musicians, and conductors including Vladimir Horowitz, John Browning, Martha Graham, Arturo Toscanini, Dmitri Mitropoulos, Jennie Tourel, and Eleanor Steber. Barber was the recipient of numerous awards and prizes including the American Prix de Rome, two Pulitzer prizes and election to the American Academy of Arts and Letters.

Vanessa was written 1957. The first performance was at the Metropolitan Opera in New York on the $15^{\text {th }}$ of January, 1958. The aria Must the winter come so soon? belongs to Act I, scene 1 of the opera. The singer is Erika, Vanessa's niece. It is night time in early winter and Vanessa, heralded by a letter, waits for her lover Anatol who abandoned her twenty years before. Erika wonders if the visitor will be able to make it through the woods and the snowy storm. The musical language is diatonic, with melodic 
writing that is well suited to the voice, a reminder of the composer's background as a singer himself. 


\section{LIST OF REFERENCES}

Alston, A. J. The Devotional Poems of Mirabai. Delhi: Motilal Banarsidass, 1980.

Di Palma, Maria and Walters Richard. Anthology of Spanish Song. Milwauke, Wisconsin: Hal $\bullet$ Leonard.

Gallo, Denise. Gioachino Rossini: A Guide to Research. New York, London: Routlede, 2002.

Fabbri, Paolo. "I Rossini, una famiglia in arte." Bollettino del Centro Rossiniano di Studi. [no.1] (1983) : 125-51.

Gossett, Philip. "Rossini e I suoi "Péchés de vieillesse." Nouva rivista musicale italiana. 14[no.1] (Jan.-Mar.1980) : 7-26.

Trend J.B. and Katz Israel J: "Cante Hondo," Grove Music Online ed. L. Macy (Accessed $[3 / 4 / 04])$, <http://www.grovemusic.com>

Kennedy, Michael. The Oxford Dictionary of Music. Oxford, New York: Oxford University Press, 1994.

Kimball, Carol. Song: A Guide to Style \& Literature. Redmond, Washington: Pst...Inc.

Larsen, Robert L. Arias for Mezzo-Soprano. New York, NY: G. Schirmer, Inc., 1991.

Mandyczewski, Eusebius. Schubert's songs to texts by Goethe. New York: Dover Publications, 1979.

Parker, Roger. The Oxford Illustrated History of Opera. Oxford: Oxford University Press, 1994.

Paton, John Glenn. 26 Italian Songs and Arias. Van Nuys, California: Alfred Publishing Co., Inc.

Simon, W. Henry. 100 Great Operas and Their Stories Act-by-Act Synopses. New York, London, Toronto, Sydney, Auckland: Anchor Books, 1957-1960.

Schelling, Andrew. For love of the Dark One: songs of Mirabai. Boston: Shambhala Publications, 1993.

Other women's voices online (accessed [12 January 04])

$<$ http://home.infionline.net/ ddisse/mirabai.html> 


\section{APPENDICES}

\section{RECITAL PROGRAM}

Già il sole dal Gange

$O$ cessate di piagarmi

Alessandro Scarlatti

Spesso vibra per suo gioco

(1660-1725)

Must the winter come so soon?

From Vanessa

Samuel Barber

(1910-1981)

Two Songs from Mirabai Songs

John Harbison

It's True I Went to the Market

Dont Go, Don't Go

(b.1938)

El amor brujo

Canción del amor dolido

Manuel de Falla

Canción del fuego fatuo

(1876-1946)

Danza del juego del amor

Las campanas del amanecer

\section{INTERMISSION}

Ständchen from Leise flehen meine Lieder

Du bist die Ruh D776

Franz Schubert

Gretchen am Spinnrade D257

(1797-1828)

Una voce poco fa

From Il barbiere di Siviglia

Gioachino Rossini

(1792-1868)

La Regata Veneziana - Three songs in Venetian dialect

Anzoleta avanti la regata

Anzoleta co pasa la regata

Anzoleta dopo la regata 
Texts and Text Translations:

\section{ALESSANDRO SCARLATTI}

\section{Giá il sole dal Gange}

Già il sole dal Gange

Più chiaro sfavilla,

E terge ogni stilla

Dell'alba che piange.

Col raggio dorato

Ingemma ogni stello,

E gli astri del cielo

Dipinge nel prato.

Text by Anonymous

\section{$O$ cessate di piagarmi}

$O$ cessate di piagarmi, o lasciatemi morir!

Luci ingrate,dispietate,

Più del gelo e più de' marmi

fredde e sorde a' miei martir.

Text by Nicola Minato

\section{Spesso vivra per suo gioco}

Spesso vibra per suo gioco

il bendato pargoletto

strali d'oro in umil petto,

stral di ferro in nobil core.

Poi languendo in mezzo al foco del diverso acceso strale per oggetto non eguale questo manca e quel vien meno.

\section{The Sun on the Ganges}

Already, from over the Ganges The sun sparkles more brightly And dries every drop

Of the dawn, which weeps.

With the gilded ray It adorns each blade of grass; And the stars of the sky It pains in the field.

Translated by Emily Ezust

\section{Oh Stop Wounding Me}

Oh stop wounding me,

$O$ leave me to die!

Eyes so ungrateful, merciless, More than ice and more than marble Cold and deaf to my sufferings!

Translated by Sara Arias Ruiz

\section{Often the Blindfolded Boy}

Often for his amusement The blindfolded boy pierces A humble breast with golden darts, A noble heart with iron arrows.

Then, amid the flames of the Burning dart, languishing in vain, One victim passes away while Another falls faint. 
Spesso vibra per suo gioco

11 bendato pargoletto

Strali d'oro in umil petto,

Stral di ferro in nobil seno.

Text by Anonymous

SAMUEL BARBER

\section{Must the winter come so soon?}

Must the winter come so soon?

Night after night I hear the hungry deer wander weeping in the woods, and from his

house of brittle bark hoots the frozen owl.

Must the winter come so soon?

Here in this forest neither dawn nor sunset

marks the passing of the days.

It is a long winter here. Must the winter come so soon?

\section{JOHN HARBISON}

\section{It's true I went to the Market}

My friend, I went to the market and bought the Dark One.

You claim by night, I claim by day. Actually I was beating a drum all the time I was buying him.

You say I gave too much; I say too little. Actually I put him on the scale before I bought him.

What I paid was my social body, my town body, my family body, and all my inherited jewels.
Often for his amusement

The blindfolded boy

Pierces a humble breast with golden darts, a noble heart with iron arrows.

Translated to English by Kenneth Chalmers 
Mirabai says: The Dark One is my husband now.

Be with me when I lie down; be with me, be with me when I lie down;

You promised me this in an earlier life.

Translated to English by Robert Bly

\section{Dont Go, Don 1 Go}

Don't go, don't go. I touch your soles, I'm sold to you.

Show me where to find the bhakti path, show me where to go.

I would like my body to turn into a heap of incense and sandalwood and you set a torch to it.

When I've fallen down to grey ashes, Smear me on your shoulders and chest.

Mira says: You who lift the mountains, I have some light,

I want to mingle it with yours.

Translated to English by Robert Bly

MANUEL DE FALLA

\section{Canción del amor dolido}

Ay! Yo no sé qué siento,ni sé qué me pasa cuando éste mardito gitano me farta. Candela qué ardes, más arde el infierno que toita mi sangre abrasa de celos!

Ay! Cuando el rio suena qué querrá decir? Ay! Por querer a otra se orvía de mí! Ay! Cuando el fuego abrasa, Cuando el rio suena,

\section{Song of the aching love}

Ah! I don't know what I feel, neither I know what happens to me when I don't have that dammed gypsy. Candela that burns, hell burns more that all my blood toasted with jealousy!

Ah! When the river murmurs what it means? To love somebody else, he forgets about me! Ah! When the fire is burning, when the river murmurs, 
si el agua no mata el fuego

A mi el penar me condena!

A mi el querer me envenena!

A mí me matan las penas! Ay!

Text by Gregorio Martinez Sierra

\section{Canción del fuego fatuo}

Lo mismo que er fuego fátuo,

Lo mismo es er queré.

Le juyes y te persigue

le yamas y echa a corré.

Lo mismo que er fuego fátuo,

lo mismito es er queré.

Malhaya los ojos negros que le alcanzaron a ver!

Malhaya er corazon triste que en su llama quiso ardé! Lo mismo que er fuego fátuo, se desvanece er queré.

Text by Gregorio Martinez Sierra

\section{Danza del juego del amor}

Tú eres aquel mal gitano que una gitana quería; el queré que ella te daba, tú no te lo mercías!

Quién lo había decí que con otra la vendías!

Soy la voz de tu destino! Soy er fuego en que te abrasas! Soy er viento en que suspiras! Soy el mar en que naufragas!

Text by Gregorio Martinez Sierra if water doesn't kill fire

I am condemned by sorrow!

Loving him is poisoning me!

Sorrow is killing me! Ah!

Translated to English by Sara Arias Ruiz

\section{Song of the Saint-EImo's Fire}

Love is the same thing, the exact same thing as Saint-Elmo's fire.

You try to run away from it and it follows you, if you call it runs away. Love is the same thing, the exact same thing as Saint-Elmo's fire.

Shame to the black eyes that discovered this love! Shame to the sad heart that in its flame wanted to burn! The same as Saint-Elmo's fire, love fades away.

Translated to English by Sara Arias Ruiz

\section{Dance of love's game}

You are that ad gypsy

that a gypsy girl used to love; the love she was giving to you, you did not deserve it!

Who could guess?

That you were unfaithful!

I am the voice of your destiny!

I am the fire in which you are burning!

I am the air in which you sigh!

I am the sea in which you are lost!

Translated to English by Sara Arias Ruiz 


\section{Las campanas del amanecer}

Ya está despuntando el día!

Cantad, campanas, cantad!

Que vuelve la gloria mia!

Text by Gregorio Martinez Sierra

FRANZ SCHUBERT

\section{Ständchen}

Leise flehen meine Lieder

Durch die Nacht zu dir;

In den stillen Hain hernieder,

Liebchen, komm zu mir!

Flüsternd schlanke Wipfel rauschen In des Mondes Licht;

Des Verräters feindlich Lauschen

Fürchte, Holde, nicht.

Hörst die Nachtigallen schlagen?

Ach! sie flehen dich,

Mit der Töne süßen Klagen

Flehen sie für mich.

Sie verstehn des Busens Sehnen,

Kennen Liebesschmerz,

Jedes weiche Herz.

LaB auch dir die Brust bewegen,

Liebchen, höre mich!

Bebend harr' ich dir entgegen!

Komm, beglücke mich!

Text by Ludwig Rellstab
Rühren mit den Silbertönen

\section{The Sunrise's bells}

The day is already beginning!

Sing, bells, sing!

That my glory returns!

Translated to English by Sara Arias Ruiz

\section{Serenade}

My songs beckon softly

through the night to you; below in the quiet grove, come to me beloved!

The rustle of slender leaf tips whispers in the moonlight; do not fear the evil spying of the betrayer, my dear.

Do you hear the nightingales call? Ah! They beckon to you, with the sweet sound of their singing they beckon to you for me.

They understand the heart's longing, know the pain of love, they calm each tender heart with their silver tones.

Lat them also stir within your breast, beloved, hear me!

Trembling I wait for you, come, please me!

Translated to English by Michel P. Rosewall 
Meine Ruh' ist hin, Mein Herz ist schwer, Ich finde sie nimmer Und nimmermehr.

Wo ich ihn nicht hab

Ist mir das Grab,

Ist mir vergälIt.

Mein armer Kopf

Ist mir verrückt, Mein armer Sinn

Ist mir zerstückt.

Nach ihm nur schau ich

Zum Fenster hinaus, Nach ihm nur geh ich Aus dem Haus.

Sein hoher Gang, Sein' edle Gestalt, Seine Mundes Lächeln, Seiner Augen Gewalt,

Und seiner Rede Zauberfluß,

Sein Händedruck, Und ach, sein Kuß!

Mein Busen drängt sich Nach ihm hin.

Ach dürft ich fassen

Und halten ihn,

Und küssen ihn, So wie ich wollt, An seinen Küssen Vergehen sollt!

Text by Johann Wolfgang von Goethe

My peace is gone, my heart is heavy, I will find it never and never more.

Where I do not have him, that is the grave, the whole world is bitter to me.

My poor head is crazy to me, my poor mind is torn apart.

For him only, I look out of the window, only for him do I go out of the house.

His tall walk, his noble figure, his mouth's smile, his eye's power,

and his mouth's magic flow, his handclasp, and ah! His kiss!

My bosom urges itself towards him.

Ah, might I grasp and hold him,

and kiss him, as I would wish, at his kisses I should die!

Translated to English by Lynn Thompson 


\section{Du bist die Ruh}

Du bist die Ruh,

Der Friede mild,

Die Sehnsucht du

Und was sie stillt.

Ich weihe dir

Voll Lust und Schmerz

Zur Wohnung hier

Mein Aug und Herz.

Kehr ein bei mir,

Und schließe du

Still hinter dir

Die Pforten zu.

Treib andern Schmerz

Aus dieser Brust!

Voll sei dies Herz

Von deiner Lust.

Dies Augenzelt

Von deinem Glanz

Allein erhellt,

$O$ fuill es ganz!

Text by Friedrich Rükert

GIOACCINO ROSSINI

\section{From Il Barbiere di Siviglia}

Una voce poco fa

Una voce poco fa

qui nel cor mi risuonò;

il mio cor ferito è già,

e Lindor fu che il piagò.

Sì, Lindoro mio sarà;

lo giurai, la vincerò.

Il tutor ricuserà,

Io l'ingegno aguzzerò.

\section{You are peace}

You are peace, the mild peace, you are longing and what stills it.

I consecrate to you, full of pleasure and pain, as a dwelling here my eyes and heart.

Come live with me, and close quietly behind you the gates.

Drive other pain out of this breast! May my heart be full with your pleasure.

The tabernacle of my eyes by your radiance alone is illumined, o fill it completely!

Translated to English by Lynn Thompson

\section{A Voice a Little While Ago}

A voice a little while ago, echoed here in my heart; my heart is wounded now, Lindoro was who covered it with wounds. Yes, Lindoro will be mine; I've sworn, I shall win. My guardian will object, I, quick-witted, will be sharp. 

Alla fin s'accheterà e contenta io resterò.
Sì, Lindoro mio sarà; lo giurai, la vincerò.
Io sono docile, son rispettosa, sono obbediente, dolce, amorosa; mi lascio reggere, mi fo guidar. Ma se mi toccano dov'e il mio debole sarò una vipera e cento trappole prima di cedere farò giocar.

Text by Cesare Sterbini

\section{La Regata Veneziana}

\section{Anzoleta avanti la regata}

Là su la machina xe la bandiera, varda, la vedistu, vala a ciapar. Co que la tornime in qua sta sera, o pur a sconderte ti pol andar.

In pope, Momolo, no te incantar. Va voga d'anema la gondoleta, né el primo premio te pol mancar.

Va là, recordite la to Anzoleta che da sto pergolo te sta a vardar. In pope, Momolo, no te incantar. In pope, Momolo, cori a svolar.

Text by Anonymous

\section{Anzoleta co passa la regata}

I xe qua, i xe qua, vardeli, vardeli, povereti i gehe da drento, ah contrario tira el vento, $i$ gha l'acqua in so favor.
In the end he will acquiesce and I will be content.

Yes, Lindoro will be mine;

I've sworn, I shall win.

I am submissive, I am respectful, I am obedient, sweet, affectionate;

I allow myself to be governed.

But if they touch me where my sensitive spot is, I will be a viper and I will cause a hundred tricks to be played before giving in.

Translated to English by Martha Gerhart

\section{The Venetian regatta}

\section{Anzoleta Before the Race}

Over there by the machine is the flag, you can see it, now go and get it. Bring it back to me this evening, or run away and hide.

Once in the boat, Momolo, don't hesitate Row the gondola with heart and soul, and then you cannot help being first.

Go on; think of your Anoleta watching from the harbor. Once in the boat, Momolo don't hesitate. Once in the boat, Momolo go with the wind.

Translated to English by Tonio Balsemin

\section{Anzoleta During the Race}

They're coming, they're coming, look at them, look at them, the poor things, they're nearly all in; the wind is against them, but the tide is running their way. 
El mio Momolo dov'elo?

Ah lo vedo, el xe secondo.

Ah! che smania! me confondo, a tremar me sento el cuor.

$\mathrm{Su}$, coragio, voga, voga, prima d'esser al paleto se ti voghi, gehe scometo, tutti indrio lassarà.

Caro, par che el svola, el li magna tuti quanti meza barca l'è andà avanti, ah capisso, el m'a vardà.

Text by Anonymous

\section{Anzoleta dopo la regata}

Ciapa un baso, un altro ancora, caro Momolo, de cuor; qua destrachite che xe ora de sugarte sto sudor.

Ah t'o visto co passando su mi l'ocio ti a butà e go dito respirando: un bel premio el ciaparà,

sì, un bel premio in sta bandiera, che xe rossa de color; gha parlà Venezia intiera, la t'a dito vincitor.

Ciapa un baso, benedeto, a vogar nissun te pol, de casada de tragheto ti xe el megio barcarol.

Text by Francesco Maria Piave
My Momolo, where is he?

$\mathrm{Ah}$, I see him, in second place. Ah! What a rage! I'm confused, ah, I feel my heart trembling.

Come on, keep it up, row, row, you will be first to the finish line, if you keep on rowing, I bet you will leave all others behind.

Dear boy, seems like you're flying, he is beating all the others, he is half a length ahead, ah now I understand, he's seen me.

Translated to English by Tonio Balsemin

\section{Anzoleta After the Race}

Catch a kiss, and now another, dear Momolo, from my heart; now relax, that is time for me to dry your sweat.
Ah, I saw you, as you passed, throwing a glance at me and I said, breathing again: he is going to win a good prize.
Indeed, the prize of this flag, the red one;
all Venice is talking about you, they have declared you the victor.

Here is a kiss, God bless you, no one rows better than you, of all the breed of gondoliers, you are the best.

Translated to English by Tonio Balsemin 


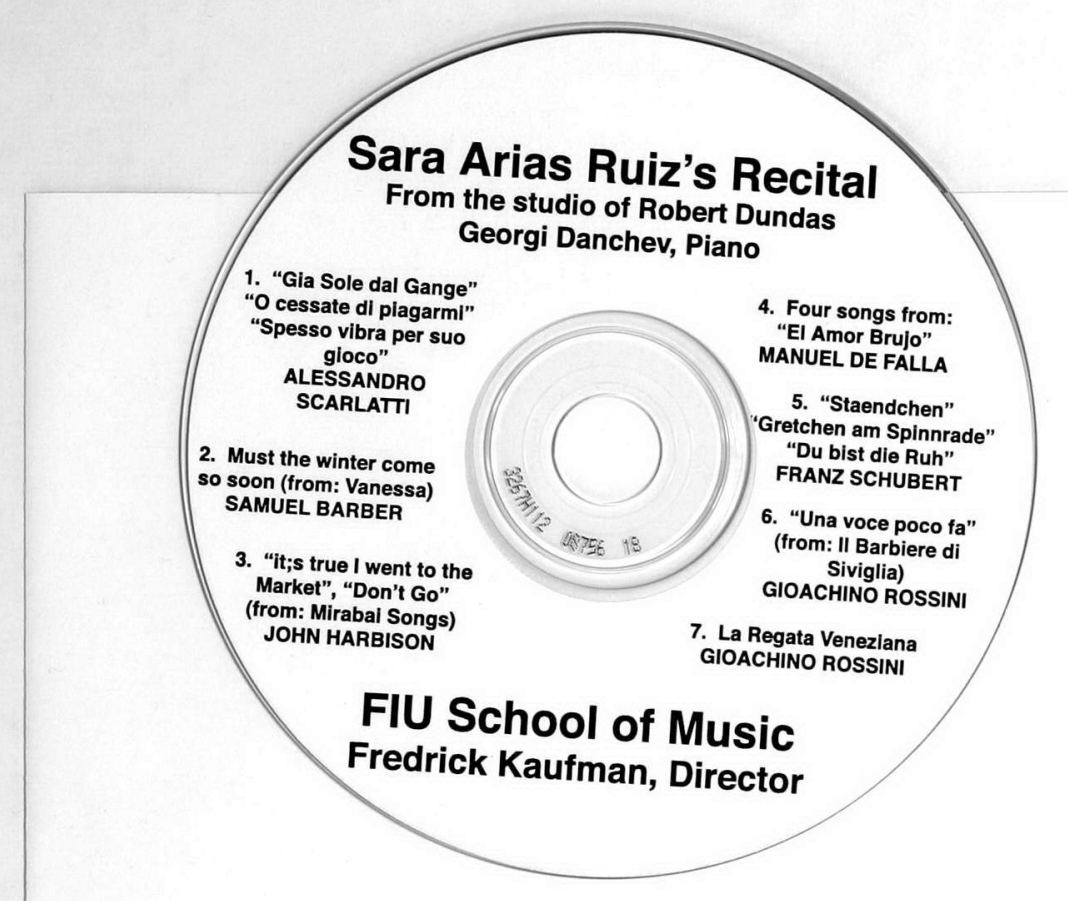

